Saint Louis University School of Law

Scholarship Commons

All Faculty Scholarship

2012

\title{
Criminal Courts and Procedure
}

Stephen C. Thaman

Follow this and additional works at: https://scholarship.law.slu.edu/faculty

Part of the Comparative and Foreign Law Commons, and the $\underline{\text { Criminal Procedure Commons }}$ 


\section{Comparative Law and Society}

Edited by

David S. Clark

Willamette University, USA

RESEARCH HANDBOOKS IN COMPARATIVE LAW

\section{Edward Elgar}

Cheltenham, UK $\cdot$ Northampton, MA, USA 
(C) The Editor and Contributors Severally 2012

All rights reserved. No part of this publication may be reproduced, stored in a retrieval system or transmitted in any form or by any means, electronic, mechanical or photocopying, recording, or otherwise without the prior permission of the publisher.

Published by

Edward Elgar Publishing Limited

The Lypiatts

15 Lansdown Road

Cheltenham

Glos GL50 2JA

UK

Edward Elgar Publishing, Inc.

William Pratt House

9 Dewey Court

Northampton

Massachusetts 01060

USA

A catalogue record for this book

is available from the British Library

Library of Congress Control Number: 2012938057

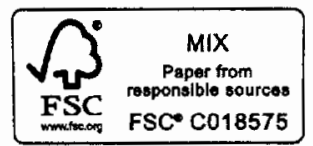

ISBN 9781849803618 (cased)

Typeset by Servis Filmsetting Ltd, Stockport, Cheshire Printed and bound by MPG Books Group, UK 


\section{Criminal courts and procedure}

Stephen C. Thaman*

\section{HISTORICAL ROOTS OF CRIMINAL COURTS AND PROCEDURE}

\subsection{The Importance of Customary Procedures: An Emphasis on Victim-offender Mediation}

Historically, when a criminal act was committed and someone caught the culprit in the act, he was either summarily killed or, at best, hurriedly sentenced to death by an ad hoc court, where the victim or the victim's family might act as executioner. ${ }^{.}$Otherwise, procedure was always accusatorial, with the victim, the victims' family or clan, accusing the suspect. ${ }^{2}$ The community then usually pressured the victim's clan or family to negotiate with that of the suspect to resolve the case peaceably and avoid blood revenge and the prospect of a long-enduring feud. ${ }^{3}$ Compromise was much more important than accurately assessing comparative guilt or punishment. ${ }^{4}$ If families or clans could not regulate the matter themselves, they would call on a mediator to resolve the dispute. ${ }^{5}$ The procedure would usually end in payment of compensation to the victim's family or clan. This payment took the form of money, livestock or other commodities. The family or clan collectively shared the guilt, which induced them to deter crimes committed by their members. The goal of the procedure was reconciliation and restoring the peace of the community, and only incidentally that of determining the truth. ${ }^{6}$

The mediators were respected problem solvers, such as chiefs or elders, who had no enforcement power, and thus required consensus and community involvement to make sure people respected the settlement. ${ }^{7}$ The mediator often worked privately with each side separately to reach a compromise. ${ }^{8}$ On the other hand, mediations would sometimes be conducted publicly in front of the entire assembled community, or a group of elders

* Professor of Law and Director, Summer Law Program in Madrid, Saint Louis University.

Thomas Weigend, Deliktsopfer und Strafverfahren 36-7 (Berlin: Duncker und Humblot 1989).

Accusation was a social function, falling to anyone in the aggrieved group. A. Esmein, $A$ History of Continental Criminal Procedure: With Special Reference to France 3-4 (Boston: Little, Brown \& Co., John Simpson trans., 1913).

3 Weigend (note 1) 13.

4 Karl N. Llewellyn and E. Adamson Hoebel, The Cheyenne Way: Conflict and Case Law in Primitive Jurisprudence 305 (New York: Legal Classics Library 1992).

5 Uwe Wesel, Geschichte des Rechts: Von den Frühformen bis zur Gegenwart 53 (Munich: C.H.Beck, 3rd edn, 2006).

6 H. Patrick Glenn, Legal Traditions of the World $68-9$ (New York: Oxford University Press, 3rd edn, 2007).

7 A.S. Diamond, Primitive Law Past and Present 185, 238-41 (London: Methuen \& Co. 1971).

8 On the similarity of mediation in European chthonic procedures and Islamic shari'a 
who would hear the arguments of both sides and try to reach a compromise settlement. Such public decision-making processes, which were common in customary societies, were the precursors of English juries or German Schöffen-courts which will be discussed below. $^{9}$

If the crime was not flagrant and immediately punished, and no 'consensual' resolution could be achieved, traditional communities often resorted to irrational forms of 'trial'. The suspect could utter a cleansing oath attesting to his innocence, and people usually accepted it, because they truly believed that someone who falsely swore would face eternal damnation. ${ }^{10}$

Many communities required the defendant to summon several friends or tribe members (often in a multiple of twelve), so-called oath-helpers or compurgators, to swear to his honesty or uprightness. ${ }^{\text {II }}$ In some communities, the swearing took on an adversarial tinge when the victim was also allowed to rebut the defendant's oath-helpers with his own. ${ }^{12}$ These groups of sworn witnesses, who had to be unanimous in their assurance of the trustworthiness of accused or accuser, represented primordial forms of early unanimous trial juries, which were expected to have knowledge of the facts of the case. ${ }^{13}$ However, this form of trial was only open to 'honorable' or upstanding citizens, and not outsiders or the poor.

Outsiders or the poor would have to engage in painful and sometimes deadly divine ordeals, often consisting in holding or walking on hot metal, reaching one's hand into boiling water or oil or having officials throw them into a cold body of water. ${ }^{14}$ In the ordeals, and in trial by battle, we see early forms of punishment of the suspicious through the functioning of the procedure itself, regardless of whether they were in the end found to be innocent or guilty. Thus, the thought of even having to go to 'trial' in these times might have been more of a deterrent than any punishment that might result from a guilt finding. Communities also used trial by battle to resolve unmediated disputes. ${ }^{15}$ Here one

proceedings in front of the qadi, see Richard Vogler, A World View of Criminal Justice 110 (Burlington, VT: Ashgate 2005).

9 In Germanic lands, judicial power was exercised directly by the people, who met in regularly held great popular courts in full assembly. Over time, however, it was only the older and most experienced men of the community, the Schoffen, who took over the role of judges. Esmein (note 2) 32 .

10 According to one Tibetan proverb: '[If the case is] clear, [decide it] by law; [if the case is] unclear, [decide it] by oath'; Rebecea Redwood French, The Golden Yoke. The Legal Cosmology of Buddhist Tibet 132 (Ithaca, NY: Cornell University Press 1995). In Europe, the oath of purgation became common with the diffusion of Roman law and the adoption of Christianity. Diamond (note 7) 300.

11 Thorl. Gudm. Repp, A Historical Treatise on Trial by Jury, Wager of Law, and other Coordinate Forensic Institutions, Formerly in Use in Scandinavia and in Iceland 21, 38 (London: Thomas Clark 1832).

12 Ian Wood, 'Disputes in Late Fifth- and Sixth-century Gaul: Some Problems', in Wendy Davies and Paul Fouracre (eds), The Settlement of Disputes in Early Medieval Europe 7, 10-14 (Cambridge: Cambridge University Press 1986).

13 Repp (note 11) 136-45.

14 Ordeals were used almost everywherc, 'from Iceland to Polynesia, from Japan to Africa'. Robert Bartlett, Trial by Fire and Water 2 (Oxford: Clarendon Press 1986).

15 Trial by battle was found in the early law codes of many Germanic peoples. Ibid. 103. 
can see the primitive beginnings of the role of a representative or attorncy in the form of 'champions' who could be hired to pitch battle on behalf of the parties. ${ }^{16}$

To summarize, traditional legal systems showed a clear preference for negotiation and mediation to avoid violence in the form of blood-revenge or feud. Confessions mitigated the severity of the penalty. ${ }^{17}$

\subsection{Politicization of Criminal Law: An Emphasis on Procedural Coercion of Confessions}

As kings and other potentates began to consolidate their power over kinship-based communities and as nations began to develop, the use of victim-offender mediation, oaths, duels and trial by battle gradually vanished and the procedure became politicized, a contest between offender and the state. ${ }^{18}$ The victim gradually disappeared as a party in criminal procedure. ${ }^{19}$ The bodies of lay judges, elders or witness-juries became co-opted and integrated into a system under the control of royal judges, as in England or under the rule of Charlemagne, ${ }^{20}$ and eventually disappeared on the European continent, yielding to courts completely in the hands of a professional royal judiciary. ${ }^{21}$ Two different systems replaced the customary forms: oral trial by jury in the British Isles and written inquisitorial trial by professional judges on the European continent.

A profound skepticism in relation to witness testimony, circumstantial evidence and the ability of men (that is, judges) to judge other men made its way into continental European inquisitorial procedure through the Roman Catholic canon law and made it extremely difficult to prove guilt in criminal cases in the absence of a flagrant crime. ${ }^{22}$ Officials perceived formal rules of evidence, preventing conviction in the absence of the testimony of at least two male, Christian eyewitnesses (or other equivalents of full proof), as a check against royal judges using their discretion to convict on less than clear evidence.

Continental procedure, which lacked the inherent legitimation provided by judgment by members of the community (jurors or Schöfen), fell to relying almost completely on confessions to prove guilt. If someone captured the suspect in suspicious circumstances that were not sufficient under the formal rules of evidence to justify conviction, and the suspect refused to confess voluntarily, he or she would be subject to torture. ${ }^{23}$

16 On the use of 'champions' to represent one in a duel or battle, see ibid. 306. Treating trial by battle as a precursor of modern adversarial procedure, Roscoe Pound in a speech before the American Bar Association in 1906 saw it as a 'sporting theory of justice'. Roscoe Pound, 'The Causes of Popular Dissatisfaction with the Administration of Justice', in Sheldon Glueck (ed.), Roscoe Pound and Criminal Justice 64 (Dobbs Ferry, NY: Oceana Publications 1965).

17 Among the Nuer in Southern Sudan, the compensation for a confessed homicide was half of that which applied in the absence of a confession. P.P. Howell, A Manual of Nuer Law 59 (London: Oxford University Press 1954).

18 On this transition, see Diamond (note 7) 339.

19 Weigend (note 1) 94.

20 Charlemagne found the old Germanic court of Schöffen already in existence when he assumed power in the eighth century and co-opted it for his own purposes. Esmein (note 2) 32.

21 The German Schoffen-court disappeared in the 1400s. Ibid. 303.

22 Ibid. 61 .

23 Ibid. $380-82$. 
Confessions did not mitigate. Authorities would execute the remorseful confessor anyway, the only mitigation being the possibility of receiving last rites from a priest. Torture replaced the painful ordeals as the new suspicious circumstances punishment. Officials imposed it whether or not one eventually confessed and was convicted. Many of those convicted were, of course, innocent. ${ }^{24}$

Inquisitorial trials were secret and based entirely on written documents in the case dossier, which the investigating magistrate pushed along to the review magistrates with little review of the credibility of the evidence.

Compared with the supposedly comprehensive investigation of the crime in continental jurisdictions, in England there was a mere cursory questioning by the justice of the peace of the suspect, witnesses and victims, theoretically to determine whether to release the suspect on bail while awaiting jury trial. Though an official did not swear-in the accused, who was not heard as a witness at trial, the justice of the peace could and often did read the accused's declaration to the jury. ${ }^{25}$ Torture was a rarity in England, yet scholars accept that the justice of the peace used coercion, or at least took advantage of the helplessness of the suspect, to get him to talk. ${ }^{26}$

With the exception of torture, the pretrial situation of the suspect in England was just as horrible as on the Continent. Suspects, the great majority of whom were not bailed, waited anywhere from six months to a year for their trial in frightful dungeons where disease was rampant. When they came to trial, they were usually ill and only learned of the precise charges at that time. As on the Continent, they had no access to counsel and had spontaneously to react to the accusations of the victim or other witnesses at trial to avoid the death penalty, which awaited all convicted felons at the time. The trial still had aspects of customary procedure-that is, a victim confronting the defendant in front of members of the community - until the cra when lawyers arrived. ${ }^{27}$

The pre-modern English procedure thus also compelled the defendant to speak. John Langbein describes the 'accused-speaks-trial' to distinguish the old arrangements from today's trials, where defendants often remain silent. ${ }^{28}$ Though no formal rules of evidence constrained the freedom of the jury to convict on the testimony of only one eyewitness, or on solely circumstantial evidence, as on the Continent, the jury provided an instance of discretion that vanished on the other side of the English Channel with the elimination of popular judges. The jury gave popular legitimation to verdicts of guilt and innocence, which may have led to conviction of some innocent persons based on circumstantial evidence, but certainly no more than were convicted based on false tortured confessions ordered in the light of similar evidence on the Continent.

Thus, both in England and on the European continent, procedures that compelled the

24 On the conviction of the innocent, see Cesare Beccaria, Dei Delitti e Delle Pene 62 (Milan: Feltrinelli, 4th edn, 1995, orig. 1764).

25 John H. Langbein, The Origins of Adversary Criminal Trial 41-3 (Oxford: Oxford University Press 2003).

26 John H. Langbein, Torture and the Law of Proof: Europe and England in the Ancien Régime 9 (Chicago: University of Chicago Press 1977).

27 Langbein (note 25) 47-51.

28 Ibid. 64 
defendant to speak and admit guilt replaced those that tried to induce or coerce victimoffender mediation. Like the guilty plea, the confession has always been the quintessential vehicle for simplifying, expediting and abbreviating both the pretrial and trial phases of criminal procedure. With a confession, there was no need for law enforcement organs to gather further evidence, other than the minimal evidence needed to corroborate the confession.

In short, the monarchies on both sides of the English Channel felt they needed disproportionately gruesome punishments to consolidate their domination and deter crime. However, the more subtle approach of the Norman rulers of England to co-opt pre-existing customary institutions and not to create a massive judicial bureaucracy to over-centralize the administration of justice, led to the lion's share of decision making by non-professional justices of the peace and jurors on a local level.

\subsection{Criminal Dispute Resolution in Asia (and Elsewhere): Staying out of Court}

In the West, the state typically sees itself ideally as the guarantor of justice and that permitting easy access to the judicial system is required to avoid resort to self-help in resolving disputes. In the East, however, the presumption is often that one should settle his or her disputes out of court and that merely setting foot in a courtroom is shameful, an unnecessary public laundering of one's sullied linens. ${ }^{29}$ The earliest paradigm for this way of thinking comes from ancient China. The Chinese emperors had at their disposal punishments as atrocious as those wielded by European autocrats. Pretrial and trial procedures did not differ much from those used in inquisitorial Europe during its darkest ages, including the primacy of the confession and the use of torture. ${ }^{30}$

Nevertheless, the rise of Confucianism provided an interesting twist to the Asian view of the role of state criminal punishment systems. According to Chinese lore, written codified criminal laws and punishments, $f a$, came from a barbarian people who used punishments instead of spiritual cultivation to rule their peoples. ${ }^{31}$ Any system that needed codified law was of necessity ruled by an ineffective emperor. According to Confucian and related thinking, the emperor should live an exemplary life by following the rituals and customs of proper living, $l i$, a kind of 'customary, uncodified law, internalized by individuals, in which

29 Reliance on out-of-court settlements, often mediated by a community elder who decides according to his cultivated ethical sense, is a Confucian legacy. Jurists consider them speedier than in-court settlements and they allow both sides to forgo the possible loss of esteem associated with a negative court decision. R.P. Peerenboom, Law and Morality in Ancient China: The Silk Manuscripts of Huang-Lao 269 (Albany, NY: SUNY Press 1993). The Vietnamese have traditionally solved disputes locally using the informal sanctions of lincages and villages, avoiding the national courts so as not to lose face and damage existing relationships. Penelope (Pip) Nicholson, Borrowing Court Systems: The Experience of Socialist Vietnam 222, 227-8 (Leiden: Martinus Nijhoff 2007).

30 The Ch'ing Code authorized torture to extract confessions from suspects, but also to extract testimony from other witnesses. Derk Bodde and Clarence Morris, Law in Imperial China: Exemplified by 190 Ch'ing Dynasty Cases 97-8 (Philadelphia: University of Pennsylvania Press 1973).

$31 \quad$ Ibid. 13. 
case no laws would ever be needed'. ${ }^{32}$ Indeed, laws were only a bad influence over people, for when they read them, they learned how to commit crimes and avoid responsibility. ${ }^{33}$ To the extent an unsuccessful victim-accuser in Asia would be subject to the same punishments that would have applied to the defendant had he been successfully convicted, there was an impetus for both victims and defendants to settle out of court. This avoided the potential harm that would beset the person who came out on the short end of the controversy.

The Confucian approach is the inevitable result of a justice system that is punitive in its very functioning, where even entering the courthouse doors results in punishment. Therefore, it is better to resolve the dispute out of court, using parallel institutions of victim-offender mediation, and applying a philosophy of flexible, consensual dispute resolution. ${ }^{34}$ There is still today a reluctance to bring disputes to court in countries with a Confucian tradition, which is strengthened by a mistrust of judiciaries that people conceived of as corrupt and untrustworthy. ${ }^{35}$

In India, and in a similar way in the classic Tibetan legal tradition, there is a preference for resolving disputes using customary procedures despite the presence of an organized state legal system. ${ }^{36}$ The ancient texts speak of legal procedures and severe punishments, but also of a hierarchy of procedures to which onc should first turn, with the official courts being the last resort. In both India and China, the preference was for first trying to resolve the dispute through ancient methods of individual self-perfection. ${ }^{37}$ An 'internal' settlement could also consist in an agreement among the parties or even customary methods such as singing contests, oaths, ordeals or even games of chance. ${ }^{38}$ If this did not quell the dispute, then the parties would resort to mediation. ${ }^{39}$ Only if these more informal methods did not bear fruit, would one resort to the court system. In Tibet, the court system consisted first in a visit to the judge and, then, if that did not end the matter, in an incredibly complex and time-consuming 44-step procedure, which ended in a trial that was humiliating in itself for the defendant, who could be whipped both before and after testifying. ${ }^{\star 0}$

32 Yongping Liu, Origins of Chinese Law: Penal and Administrative Law in its Early Development 97 (Oxford: Oxford University Press 1998). One can find a similar anti-legal attitude in Indian history and culture. Werner Menski, Comparative Law in a Global Context: The Legal Systems of Asia and Africa 203 (Cambridge: Cambridge University Press, 2nd edn, 2007).

33 Bodde and Morris (note 30) 16-17. In the words of Confucius, "the more laws $(f a)$ and ordinances (ling) are promulgated, the more thieves and robbers there will be', Ibid. 22.

34 Glenn (note 6) 313-14.

35 In Vietnam, people avoid the courts because they are arbitrary and politically controlled. In rural areas, and among the poor, anywhere from 40 to 50 percent of the people do not even know a court system exists. Nicholson (note 29) 228, 269-70. On a resurgence of Confucian values in the People's Republic of China, see Glenn (note 6) 333.

36 In Tibet, the goal of a legal proceeding was to calm the minds and relieve the anger of the disputants and then, through catharsis, expiation, restitution and appeasement, to achieve consensus and rebalance the natural order. French (note 10) 74 .

37 It is still in China a commonplace that when conflicts arise, one is well advised to begin with qing, appeal to the other's feelings, emotions, sense of humanity or common decency. Peerenboom (note 29) 268.

38 French (note 10) 121.

39 On mediation in Tibet, see ibid. 122. On informal mediation and negotiation within the parties' socio-cultural spheres in India, sce Menski (note 32) 218, 258.

at French (note 10) 123-5, 322. 
In India today, one reads about 'state legal systems' and 'non-state legal systems', such as local caste or regional panchayats, which resolve disputes in ways reminiscent of the old European popular courts. ${ }^{41}$ The emphasis is on reconciliation, compromise and restoring the peace of the community, and less on ascertaining truth and imposing punishment.

In both Talmudic and Islamic doctrine, there is also a preference for out-of-court settlement of disputes. Talmudic law teaches that disputants should seek compromise and that it is preferable for the judge to compromise rather than to let the law 'cut through the mountain', thus creating a winner and a loser and causing the dispute to fester on. ${ }^{42}$ In Islamic law, as well, accuser and accused should try to resolve their dispute with a mufti out of court before resorting to qadi justice, which, though based on interpretation of the Qu'ran and other Islamic texts rather than on the pure goal of restoring the legal peace, nevertheless looks a lot like mediation in customary law societies. As in customary law systems, the confession plays a mitigating role in traditional Islamic law, though, unlike in China and inquisitorial Europe, coercion of confessions was forbidden and a confession could be retracted at any time with impunity. ${ }^{43}$

Parallel 'non-statc' systems do not, as such, exist in most Western countries, yet one can see victim-offender mediation and some types of diversion as variants of this notion of keeping criminal disputes out of the 'state legal system'. In this respect, it is interesting to see the influence of Native American law on victim-offender mediation in Canada and the United States with the use of methods derived from indigenous 'sentencing circles' and other customary law institutions. ${ }^{44}$ Parallel systems based in customary indigenous law also exist in Latin America, for instance, in Nicaragua, Bolivia and Colombia.

Customary legal traditions also survive among certain African tribes. Some African countries provide for assessors in criminal trials who are experts in customary law. But the most interesting rebirth of such traditions has been in the gacaca tribunals in Rwanda, which are being used to try low-level suspects in that country's 1994 genocide, who cannot be accommodated by the International Criminal Tribunal for Rwanda and the domestic Rwandan courts. ${ }^{45}$

The traditional Asian approach to dispute resolution contains within it a different

41 India has, according to one writer, three types of 'non-state legal systems:' caste-based, community-based and innovative-reformist. These panchayats are normally composed of five individuals. Upendra Baxi, 'People's Law in India - The Hindu Society', in Masaji Chiba (ed.), Asian Indigenous Law: In Interaction with Received Law 216, 235-6 (London: KPI 1986).

42 Maimonides wrote that the judge "must attempt in all his cases to have the parties compromise. If he can succeed in never deciding a case on the law, by always effecting a compromise, how praiseworthy is his accomplishment! If he is not able [to effect a compromise in a particular case], he must apply strict law'. Menachem Elon, Bernard Auerbach, Daniel D. Chazin and Melvin J. Sykes, Jewish Law (Mishpat Ivri): Cases and Materials 262, 267 (New York: Matthew Bender 1999).

${ }^{43}$ Muslim scholars claim that Islamic law was the first to recognize the presumption of innocence, the burden of proof on the accuser, and to prohibit torture and pretrial detention. Vogler (note 8) 114. They argue that the presumption of innocence burden of proof, prohibition on pretrial detention, prohibition against torture and the rights to silence and defense are all found in the Qu'ran. Ibid. 114.

44 Glenn (note 6) 68-9.

45 See generally Nancy Amoury Combs, Guilty Pleas in International Criminal Law: Constructing a Restorative Justice Approach 212-18 (Stanford, CA: Stanford University Press 2007); Mark A. 
notion of 'truth' than one finds in the inquisitorial continental European tradition or in the Anglo-American view that adversarial confrontation best reveals the truth. Thus, in many of these traditions, 'truth' is equated with 'peace' and the elimination of the anger and frustration caused by confrontation in a trial situation, which might lcad to further violence or disputes in the future. ${ }^{46}$

\subsection{The European Enlightenment: Development of the Anglo-American Adversarial Trial and the European Mixed-inquisitorial System}

The model for criminal procedure for both the United States and France in the late eighteenth century, and for the rest of Europe in the nineteenth century, was the new 'lawyerized' criminal trial, which had developed in England in the mid-eighteenth century. From the 1720 s to the 1760 s, English law turned about-face from a 'ringing endorsement' of confessions to the opinion that confessions were the 'weakest and most suspicious of evidence'. ${ }^{47}$ With the gradual admission of lawyers in felony cases in the eighteenth century, the procedure became adversarial and the right to the defendant's silence became entrenched, ${ }^{48}$ thus giving substance to the presumption of innocence and the prosecutorial burden of proof beyond a reasonable doubt. Defendants began letting their lawyers talk for them at trial and judges began to accept guilty pleas with a tacit promise of mitigation accompanying them.

On the European continent, the Enlightenment brought with it over the course of the nineteenth century the abolition of torture and the gradual introduction of a public trial before a jury. The early revolutionary period in France coincided with a profound distrust of professional judges and their ability justly to decide cases. ${ }^{49}$ Despite the mistrust of judges, the preliminary investigation remained in the hands of an investigating magistrate, was secret and the defendant had little chance to influence the decision-making process. Comparatists have called this form of procedure, with an oral trial but secret inquisitorial preliminary investigation, the 'mixed' form, as it includes both adversarial and inquisitorial aspects. ${ }^{50}$

In the continental European version of jury trial, a special verdict, which consisted of a list of questions addressed to the jury about elements of the charged crimes and possible

Drumbl, 'Law and Atrocity: Settling Accounts in Rwanda', 31 Ohio Northern University Law' Review 41 (2005).

46 In Tibet, people view truth as consensus on the facts. If a dispute that appeared settled flares up in the future, it has not been resolved. French (note 10) 137-8.

$47 \quad$ Langbein (note 25) 233.

48 Langbein believes that the privilege against self-incrimination was only officially recognized in England around 1898. Ibid. 280. Nevertheless, for a law of 1848 implementing the right to silence along with cautions, see Vogler (note 8) 147.

49 John Henry Merryman and Rogelio Pérez-Perdomo, The Civil Law Tradition: An Introduction to the Legal Systems of Western Europe and Latin America 15-16 (Stanford, CA: Stanford University Press, 3rd edn, 1985). Pound cited references to these judges as 'legal monks', utterly ignorant of human nature and the affairs of men. Pound (note 16) 57.

50 Esmein (note 2) 3. On the oral trial of this epoch as a mere 'repetition', or 'mis-en-scène' of the preliminary investigation, see Luigi Ferrajoli, Diritto e ragione: Teoria del garantismo penale 578 (Rome: Laterza, 5th edn, 1998). 
defenses, still required the judge to interpret the verdict and issue a reasoned judgment. With few exceptions, the notion of pleading guilty and moving directly to the imposition of punishment was anathema on the European continent ${ }^{51}$ and in Latin America, where none of the liberal changes triggered by the French Revolution was introduced.

In Europe, authorities facilitated confessions by the expansive use of pretrial detention of defendants ${ }^{52}$ and provisions in criminal codes that accorded statutory mitigation to confessing and remorseful defendants. Defendants also usually always testified in cases before a purely professional bench or a mixed court of lay and professional judges, because there was no separate sentencing stage, which would allow them to remain silent at trial and then provide evidence of mitigation relating to sentence. ${ }^{53}$

As guilty pleas began to be accepted in England and the US in the nineteenth century, plea bargaining was not as necessary to save time and resources, because trials were still relatively rapid. Whereas a jury in the early 'accused-speaks' trial in England sometimes heard as many as ten cases a day before retiring to deliberate on all of them simultaneously, even the later 'lawyerized' trials of the nineteenth century were quite rapid. There is, however, evidence that judges would sentence in a milder fashion upon acceptance of a guilty plea than after a jury verdict of guilt. ${ }^{54}$

Trials in inquisitorial systems were also speedy affairs, whether conducted in one session (as in Spain) or in installment fashion as in Germany. ${ }^{55}$ The procedural inducement of admissions of guilt during the preliminary investigation, through aggressive interrogation or the promise of freedom from pretrial detention upon confessing, or at trial, as a means of sccking mitigation, worked in a similar manner as guilty pleas. Indeed, some writers have considered such procedural arrangements as the equivalent of plea bargaining. ${ }^{56}$

\subsection{Jury Courts, Mixed Courts and Professional Courts}

People have traditionally considered the criminal jury, with its roots in ancient England, to represent the conscience of the community. Its decisions were imbued with inherent

51 The Spanish Code of Criminal Procedure of 1872 and the Russian Code of Criminal Procedure, in force from 1864 until 1917, also allowed for an admission of guilt. Stephen C. Thaman, 'A Typology of Consensual Criminal Procedures: An Historical and Comparative Perspective on the Theory and Practice of Avoiding the Full Criminal Trial', in Stephen C. Thaman (ed.), World Plea Bargaining: Consensual Procedures and Avoidance of the Full Criminal Trial 297, 323 (Durham, NC: Carolina Academic Press 2010).

52 On pretrial detention as a sanction imposed due to suspicion or as 'masked torture', see Ferrajoli (note 50) 336, 562-6.

53 Mirjan Damaška, 'Models of Criminal Procedure', 51 Zbornik Pravnog fakulteta u Zagrebu 477,487 (2001).

54 George Fisher, Plea Bargaining's Triumph 159 (Stanford, CA: Stanford University Press 2003).

55 On the 'piecemeal' or 'installment' approach to criminal trials, especially in Germany, see Mirjan R. Damaška, The Faces of Justice and State Authority 52 (New Haven, CT: Yale University Press 1986).

56 See David T. Johnson, 'Plea Bargaining in Japan', in Malcolm M. Feeley and Setsuo Miyazawa (eds), The Japanese Adversary System in Context 140, 144-5 (New York: Palgrave Macmillan 2002). 
legitimacy: the jury 'spoke the truth' through its verdict, ${ }^{57}$ which needed no other justification. ${ }^{58}$ People accepted the verdict, as they would the results of a democratic election or parliamentary vote-even when the results appeared, on occasion, to be irrational. ${ }^{59}$ Juries in the US and the United Kingdom return general verdicts. These merely declare the defendant (or defendants) 'guilty' or 'not guilty' of the charged crimes. Jurists can discover the logic of the verdict only by studying the record of the evidence adduced, the instructions given by the judge on the law and its application in the particular case.

In civil law Europe and Latin America, popular juries do not have the centuries-long and uninterrupted pedigree that they enjoy in the common law world. As explained above, only with the French Revolution and the Enlightenment critique of the brutality of the confession-based inquisitorial procedure did the inquisitorial system based on formal rules of evidence and torture give way to jury trial. The new French model allowed juries to decide based on its intime conviction (inner conviction, or conscience) and made its decision, in cases of acquittal, final. ${ }^{60}$ Jury verdicts were by majority vote and the verdict was in the form of itemized question lists. ${ }^{61}$

Although the French accepted the English jury's freedom freely to evaluate evidence, the question-list form of verdict enables the bench to see the logic of how the jury decided the case. This allows judges to draft a written judgment based on the jury's factual answers. The judgment provides the legal qualification of the criminal facts that the jury found proved. ${ }^{62}$ Yet the same Enlightenment thinkers who pushed for adopting the jury and free evaluation of the evidence were just as adamantly against professional judges doing anything but subsuming the facts to the law. As Charles-Louis de Montesquieu (1689 1755) famously said, 'the judges of the nation are nothing, as we have said, but the mouth which

57 For an opinion that the term verdict (truth-saying) is 'euphemistic' and was an attempt to transpose the unerring correctness of all decisions of an absolute monarch to that of a popular jury, see Reinhard Moos, 'Die Begründung der Geschworenengerichtsurteile', 132 Juristische Blätter 73, 76 (2010).

58 In the United States, verdicts, whether 'guilty' or 'not guilty', were final upon their pronouncement and not subject to appeal until 1889. United States v. Scott, 437 U.S. 82, 88 (1978).

59 Thus, Thomas Jefferson remarked once in a letter to a friend: 'Were I called upon to decide, whether the people had best be omitted in the legislative or judiciary department, I would say it is better to leave them out of the legislative. The execution of the laws is more important than the making of them.' Quoted in Jeffrey Abramson, We, the Jury: The Jury System and the Ideal of Democracy 30 (Cambridge, MA: Harvard University Press 2000).

60 Stephen C. Thaman, Comparative Criminal Procedure: A Casebook Approach 205 (Durham, NC: Carolina Academic Press, 2nd edn, 2008).

61 See section 1.2. On the French special verdict, see Bernard Schnapper, 'Le jury français aux XIX et XXème siècles', in Antonio Padoa Schioppa (ed.), The Trial Jury in England, France, Germany: $1700-1900$ at 168, 178-9 (Berlin: Duncker and Humblot 1987). On the question lists used in Russia and Spain today and in the nineteenth century, see Stephen C. Thaman, 'The Nullification of the Russian Jury: Jury-Inspired Reform in Eurasia and Beyond', 40 Cornell International Law Journal 357, 379-99 (2007); Stephen C. Thaman, 'Spain Returns to Trial by Jury', 21 Hastings International and Comparative Law Review 241, 321-53 (1998).

${ }_{62}$ On the question lists and the role of the judge in drafting a judgment in the modern Russian and Spanish jury systems, see Stephen C. Thaman, 'Europe's New Jury Systems: The Cases of Spain and Russia', in Neil Vidmar (ed.), World Jury Systems 319, 338-47 (Oxford: Oxford University Press 2000). 
pronounces the words of the law; inanimate beings who can moderate neither its force, nor its rigor". ${ }^{63}$

This mechanistic approach to the role of the judge only gradually took hold in Germany, where a diametrically opposed notion of the judge had developed during the eighteenth century. According to early German Enlightenment thinkers, the judge should act as a creative savior of imperfect laws through his wise application of principles of natural law, and should nullify unwise laws and acquit suspected criminals despite the word of the law. ${ }^{64}$

Jury courts have never been the default jurisdiction for criminal cases on the European continent. In all non-jury courts, the judge is required to decide whether facts were proved based on his or her 'inner conviction', as would a juror. Nevertheless, in Europe there was a general reluctance to allow professional judges to decide freely, without being bound by rules of evidence of some kind. In 1846, the great German jurist, Friedrich Carl von Savigny (1779-1861) suggested a compromise when he was Prussian minister of justice. He suggested that judges would be bound in their evaluation of the facts to the 'laws of thought, experience and human knowledge'. In the same year, a Berlin ordinance instituted the requirement that the judge give reasons for his decisions. "The judge as trier of fact must from now on decide whether the defendant is guilty or not guilty, based on a careful appraisal of all evidence for the prosecution and the defense according to his free conviction, resulting from the essence of the trial held in his presence. He is, however, obligated to give the reasons, which guided him, in the judgment'. ${ }^{65}$ What Germans called 'free evaluation of the evidence' (freie Beweiswürdigung) gradually became infused with a meaning that radically diverged from the French intime conviction, which some now criticized as being irrational. ${ }^{66}$ Jurists characterized the German approach as 'reasoned conviction' (conviction raisonée). ${ }^{67}$

Throughout the nineteenth and into the twentieth century, the continental jury remained the typical court for the trial of murders and other serious felonies. However, the German mixed court (Schöffengericht)-which is for less serious crimes and in which professional and lay judges deliberate collectively, thus allowing the professional judge to write a reasoned judgment-began to win adherents in other countries. ${ }^{68}$ Nevertheless, it was only with the rise of Bolshevism and fascism in Europe that the anti-jury forces were able to deal a clear blow to the English transplant. The Bolsheviks

\footnotetext{
63 Montesquieu, 1 De L'Esprit des Lois 301 (Paris: GF-Flammarion 1979, orig. 1748).

64 Wilfried Küper, Die Richteridee der Strafprozeßordnung und ihre geschichtlichen Grundlagen 3942 (Berlin: De Gruyter 1967).

65 Regulation (Verordnung) of 17 July 1846, reprinted in Andreas Geipel, Handuch der Beweiswïrdigung 11 (Münster: ZAP 2008).

66 Damaška has characterized the French notion of intime conviction as 'romantic' and compared it with the German approach whereby the judge no longer had the "license to disregard the extralegal canons of valid inference'. Mirjan R. Damaška, Evidence Law Adrift 21 (New Haven: Yale University Press 1997).

67 Gunter Deppenkemper, Beweiswürdigung als Mittel prozessualer Wahrheitserkenntnis: Eine dogmengeschichtliche Studie zu Freiheit, Grenzen und revisionsgerichtlicher Kontrolle tatrichterlicher Überzeugungsbildung ( $\$ 261$ StPO; $\$ 286$ ZPO) 208 (Göttingen: V \& R Unipress 2004).

68 In France, the influential jurist Gabriel Tarde pushed for mixed courts as early as 1877. Vogler (note 8) 236-7.
} 
eliminated the jury in 1917 and substituted a mixed court similar in form (one professional judge and two lay assessors) to the one in the 1877 German Code of Criminal Procedure. ${ }^{69}$

The German jury was transformed into a mixed court in 1924 by decree of the minister of justice, supposedly as a cost-saving measure during an economic depression. ${ }^{70}$ The fascists in Italy (in 1922), Portugal (in 1927) and Spain (in 1939) also eliminated the jury, with the Italians converting it into a mixed court. In 1941, the Vichy regime in France converted its jury into a mixed court. ${ }^{71}$ By the end of World War II, the European jury was only present in its French form in Belgium, Austria, some of the Swiss cantons, Denmark and Norway. ${ }^{72}$

\section{MODERN CRIMINAL COURTS AND PROCEDURE}

\subsection{The Human Rights Revolution: From Inquisitorial to Adversarial Procedure}

The defeat of German and Italian fascism in 1945, the democratization of Spain in 1978, the collapse of the Soviet Union in 1991 and the gradual removal of military dictatorships in Latin America led to a raft of new constitutions and codes of criminal procedure that have introduced a progressive array of procedural rights for defendants. The indisputable trend is away from the old inquisitorial model to an adversarial one. ${ }^{73}$

The centerpiece of inquisitorial procedure was always the preliminary investigation, traditionally carried out by an investigating magistrate who was usually a member of the judiciary. Even after the inquisitorial systems were reformed to include an oral trial by jury, most systems allowed reading of the reports contained in the dossier of the preliminary investigation to the jury (or the judge or mixed court where no jury was available). This constituted a pre-packaging of evidence by law enforcement organs with no opportunity for the defense to see or confront the witnesses. Some countries allowed minimal participation of defense counsel. For instance, France, since 1897, has allowed participation of counsel during judicial interrogations of the suspect, but this was of little help to the suspect, because the code allowed unfettcred interrogation of the suspect by the

69 Stcphen C. Thaman, 'The Resurrection of Trial by Jury in Russia', 31 Stanford Journal of International Law 61, 65 7 (1995).

70 Christoph Rennig, Die Entscheidungsfindung durch Schöffen und Berufsrichter in rechtlicher und psychologischer Sicht 57-59 (Marburg: N.G. Elwert 1993).

71 Neil Vidmar, 'The Jury Elsewhere in the World', in Vidmar (note 62) 429-32.

72 John D. Jackson and Nikolay P.Kovalev, 'Lay Adjudication and Human Rights in Europe', 13 Columbia Journal of European Law 83, 95 (2006).

73 On the accusatorial and adversarial reforms in the former Soviet republics, see Stephen C. Thaman, 'The Two Faces of Justice in the Post-Soviet Legal Sphere: Adversarial Procedure, Jury Trial, Plea-Bargaining and the Inquisitorial Legacy', in John Jackson, Máximo Langer and Peter Tillers (eds), Crime, Procedure and Evidence in Comparative and International Context: Essays in Honour of Professor Mirjan Damaska 99-118 (Oxford: Hart Publishing 2008). On Latin American reforms, see Máximo Langer, 'Revolution in Latin American Criminal Procedure: Diffusion of Legal Ideas from the Periphery', 55 American Journal of Comparative Law 617, 629 (2007). 
police with no right to counsel before the police turned the case over to the investigating magistrate. ${ }^{74}$

Some jurists began to question the role of a judicial official as investigator, because the same investigating magistrate who decided the legality of arrests, orders of pretrial detention, searches and wiretaps was also conducting the investigation. They questioned whether a person could develop his/her own particular theory of guilt in a case and be independent, neutral and judicial when deciding whether the human rights of the suspect should be infringed. Since the police, in reality, did the lion's share of actual criminal investigation, and the prosecutor was responsible in most countries for preferring the charges, the typical solution was to put the prosecutor in charge of the preliminary investigation. This reduced the judicial role to that of a liberty or control judge, a neutral arbiter of invasions of human rights (authorizations of arrests, pretrial detention, seizures, searches or wiretaps) who would also preside over interrogations. Germany took this step in 1974, Italy in 1988 and Venezuela and other Latin American countries in the 1990s. In the Soviet Union and its socialist client states in Eastern Europe it was the public prosecutor who not only supervised the preliminary investigation, which was in the hands of an investigator provided by the ministry of the interior, but also authorized all invasions of protected human rights of suspects. All of the European socialist bloc countries except Belarus, however, have now ratified the European Convention of Human Rights (ECHR). The case law of the European Court of Human Rights (ECtHR) has required them to provide for judicial authorization of these measures. Similar reforms have also taken place in most of the former Soviet republics in central Asia. ${ }^{75}$

Increased recognition of the right to confront witnesses, guaranteed, inter alia, by article $6(3)$ (d) of the ECHR, has led formerly inquisitorial countries to require the presence of the defendant or defense counsel, where possible, while prosecution witnesses are being examined during the preliminary investigation. The ECtHR has repeatedly condemned the use of written statements when they are the sole or main cvidence of guilt in criminal cases if the defendant had no pretrial chance to confront and examine the witness. The 1988 Italian Code of Criminal Procedure requires the prosecutor to initiate a hearing to preserve witness testimony in cases where it is likely that the witness may not be available for trial. At these depositions, the defendant and the victim have the right to be present and examine the witness. Otherwise, the prosecution cannot use the statement at trial. Similar provisions exist in the 1995 Spanish Jury Law and in new Latin American codes of criminal procedure ${ }^{76}$ Thus, procedure in formerly inquisitorial countries is now becoming closer to that which reigns in the US, where a 2004 decision of the US Supreme Court further strengthened the inadmissibility of written statements. ${ }^{77}$

In Italy and in cases subject to Spain's new jury law, the investigative dossier is, in principle, not to be used during the trial as a source of evidence. Officials compile a special trial dossier, including the accusatory pleading and any evidence that has been properly preserved for trial, guaranteeing defense rights of confrontation as noted above. Some

74 Stephen C. Thaman, 'Penal Court Procedures, Doctrinal Issues in', in David S. Clark (ed.),

3 The Encyclopedia of Law and Society 1096, 1099 (Thousand Oaks, CA: Sage Publications 2007).

75 Ibid.

76 Ibid.

77 Crawford v. Washington, 541 U.S. 36 (2004). 
formerly inquisitorial countries have gone a step further, however, by allowing parallel defense investigations such as exist in the US. The 1988 Italian Code provides for defense gathering of evidence in preparation for the trial phase. Code amendments in 1999 provide for detailed procedures to regulate the gathering of this evidence and its eventual unification with the prosecution evidence in a common investigative file. The Russian Code of 2001 has also taken the step of allowing defense investigations. ${ }^{78}$

The trial judge in the mixed systems on the European continent traditionally acted like the quintessential investigator. After reviewing the investigative dossier, she decided which witnesses to call and she did the examination of the witnesses at trial. Since she had reviewed the investigative dossier and had it at hand, she was aware of the inculpatory premises put forward by the investigating magistrate and had usually adopted them, for she had to decide pretrial whether there was sufficient evidence to set the case for trial. It stretches the imagination to believe that such a trial judge actually entertained a presumption of the innocence of the defendant in such a procedure. Unsurprisingly, the written judgment would often closely follow the language of the written accusatory pleading. ${ }^{79}$

On top of that, the defendant was called to answer the charges at the beginning of the trial and asked to give a statement before any other witnesses were called or evidence presented, seemingly belying the fact that the burden was on the state to prove the charges. The judge then examined the defendant, using the materials in the dossier to guide her in the 'search for the truth'. The prosecutor and defense counsel would be able to submit questions (often only in writing to the presiding judge) to supplement the examination of the judge. If witnesses did not appear, the presiding judge would merely read the statements they had made to the investigating magistrate during the preliminary investigation. ${ }^{80}$

As long as European systems still had juries, the trial judge was not a judge of the facts and therefore the fact that the judge was not neutral did not necessarily directly affect the outcome of the case. But when most European systems eliminated the jury in favor of professional or mixed panels, then the same judge who 'investigated' the case at trial, using his inquisitorial skills and who had adopted the findings of the investigating magistrate, also decided the case. The adversarial model is gradually replacing this system, which still largely exists in France, Germany, the Netherlands, Belgium and other countries. In the advcrsarial model, the prosecution and defense are responsible for preparing and presenting the evidence and questioning the witnesses. The judge assumes the more passive role of deciding questions of admissibility of evidence and guarantying the parties have 'equality of arms' in presenting their cases. ${ }^{81}$

The 'search for truth' at all costs during the criminal trial has also suffered as a result of a growing recognition that evidence gathered in violation of the human rights of criminal suspects should not be used in the criminal trial even if it is otherwise relevant and credible evidence of guilt. These violations typically occur against the right to privacy, the right to human dignity or the privilege against self-incrimination. The US Supreme Court took

Thaman (note 74) 1100.

Ibid.

Ibid.

Ibid. 
this step in 1961 with the landmark decision of Mapp v. Ohio. ${ }^{82}$ The Court's famous 1966 decision in Miranda v. Arizon ${ }^{83}$ greatly influenced the majority of European and Latin American countries. They now require interrogators to advise a criminal suspect of the right to silence and the right to talk to a lawyer before the state's agents question them. A failure to do so often results in a prohibition on the use of the ensuing statements. ${ }^{84}$

In many Western countries, such as Germany, the UK, Canada, Australia and New Zealand, the search for truth still prevails in the end because courts take a very cautious approach to exclusion of evidence, engaging in an elaborate balancing process that in the end only excludes evidence gathered in the most egregious ways. In Italy and Spain, legislatures have passed laws that require exclusion of such cvidence, yet only the Spanish courts have enforced this law with any vigor. The Russian Constitution of 1993 mandates exclusion of illegally gathered evidence, as do most of the new post-Soviet constitutions and many new Latin American constitutions. ${ }^{85}$

In the US, the 1960 s human rights revolution was spearheaded by the decisions of the Supreme Court under Chief Justice Earl Warren (served 1953-69). These finally succeeded in extending the protection of the US Bill of Rights to the entire population and in guaranteeing equal protection of the laws to African-Americans and other minorities. But the irony of this and other such 'revolutions', and the ensuing improvements in the protection of suspects and defendants in criminal proceedings, is that the states who recognize them are not willing or able to pay for the more complicated and protective procedures that the respect for these human rights necessitate. ${ }^{86}$

\subsection{The First Counter-Revolution: Plea Bargaining and Other Consensual Processes}

Plea bargaining has been expanding, in fits and starts, in the United States and now accounts for more than 95 percent of all criminal judgments. ${ }^{87}$ Ironically, the reforms of the Warren Court in expanding the ability of the defendant to participate fully and on an equal footing with the prosecutor in the adversarial trial by jury have been substantially negated by a system of plea bargaining. Under that process, threats of Draconian punishments successfully compel nearly all defendants, whether guilty or not, to renounce their newly won rights and to plead guilty. ${ }^{88}$ Although Spain and Russia

\footnotetext{
82367 U.S. 643 (1961).

83384 U.S. $436(1966)$.

84 On the spread of Miranda, see Stephen C. Thaman, 'Miranda in Comparative Law', 45 Saint Louis University Law Journal 581 (2001).

85 On the use of balancing tests, see Stephen C. Thaman, 'Constitutional Rights in the Balance: Modern Exclusionary Rules and the Toleration of Police Lawlessness in the Search for Truth' 61 University of Toronto Law Journal 691-736 (2011).

86 For an opinion that the activation of the right to counsel and the development of restrictive rules of evidence constituted the first steps towards making English-style jury trial unworkable without a guilty plea system, see John H. Langbein, 'Torture and Plea Bargaining', 46 University of Chicago Law Review 3, 11 (1978).

${ }_{87}$ The guilty plea rate in federal courts was around 90 percent in 1949 to 1951 , fell to 79 percent around 1980 , only to rise to 94 percent by the end of the twentieth century. Fisher (note 54) 222-3.

88 On how increasingly harsh sentences over the last 20 years, coupled with steep discounts during plea bargaining, have made the US system coercive, see Jenia Iontcheva Turner, "Judicial
} 
have introduced new jury systems and both countries guarantee an adversarial trial with strong exclusionary rules, they are also expanding the use of forms of plea bargaining to limit the number of cases tried in the jury courts. ${ }^{89}$ In Germany, the growing cleverness of lawyers in exploiting German procedural and evidentiary rules to draw out trials and make prosecutors and judges work longer hours has led to an increasing use of informal confession bargaining to achicve procedural economy. According to this procedure, the judge will offer a defendant a reduced sentencing range if he agrees to confess in open court. ${ }^{90}$ In Italy, the drafters of the 1988 Code of Criminal Procedure intended it to move Italy towards an oral adversary trial with minimal use of hearsay and written testimony, similar to that in the US but without a jury. However, it also included the largest assortment of alternative procedures to avoid these expanded due process protections, including, ironically, one that allows the defendant to agree to having a written inquisitorial trial based on the material in the investigative dossier. ${ }^{91}$

In the literature, one reads of a growing reprivatization of criminal procedure. The paradigm of the victim and the culprit reconciling, following a show of remorse and acts of restitution or compensation, with its roots in the ancient history of criminal procedure, is very much alive today. Many new reforms of criminal procedure provide for reconciliation between victim and offender, mainly in the case of less serious crimes. The restoration of the judicial peace is the proclaimed goal of such procedures, rather than the ascertainment of the truth. ${ }^{92}$

The trend in Europe and Latin America towards adversarial procedure has also been coupled with the introduction of 'consensual' procedures to dispose of lesser offenses, which sometimes look similar to US plea bargaining. Penal orders, originally introduced in Prussia in the first half of the nineteenth century, allow the prosecutor to send the defendant a proposed judgment in cases involving minor crimes that normally do not include sentences to jail. The defendant is given a short time (usually from one to three weeks) to accept or decline the proposal. ${ }^{93}$ The 1988 Italian Code of Criminal Procedure includes penal orders, but also allows the accused to make a 'request for application of punishment' if charged with a crime, the maximum term of imprisonment for which does not exceed five years, and her punishment will be reduced by one third. France (in 2004) and Russia (in 2001) introduced a similar procedure, which in Russia is now applicable to crimes punishable by up to ten years, and similar

Participation in Plea Negotiations: A Comparative View', 54 American Journal of Comparative Law 199, 202-04 (2006).

89 Thaman (note 51) 328.

90 Marcus Dirk Dubber, 'American Plea Bargains, German Lay Judges, and the Crisis of Criminal Procedure', 49 Stanford Law Review 547, 568-72 (1997). So-called Absprachen were finally codified in 2009. Karsten Altenhain, 'Absprachen in German Criminal Trials', in Thaman (ed.), World Plea Bargaining (note 51) 157, 179.

91 William T. Pizzi and Luca Marafioti, 'The New Italian Code of Criminal Procedure: The Difficulties of Building an Adversarial Trial System on a Civil Law Foundation', 17 Yale Journal of International Law 1 (1992).

92 Stephen C. Thaman, 'Consensual Penal Resolution', in Clark (ed.) (note 74) 1: 247. On victim-offender mediation, see Thaman (note 51) 335-9.

93 On penal orders, see Thaman (note 51) 339-42. 
procedures have been adopted in other new codes in former Soviet republics and in Latin America. ${ }^{94}$

Wide-open US-style plea bargaining, in which the prosecutor can threaten a defendant with death, life imprisonment or decades of prison, in order to induce a guilty plea to a lesser sentence, ${ }^{95}$ has found few adherents as of yet around the world. ${ }^{96}$ Indeed, the coercive nature of US plea bargaining has its doctrinal roots more clearly in the inquisitorial procedures that coerced confessions than in the victim-offender mediation typical of pre-inquisitorial customary law.

Most consensual processes aim to economize on court time and unburden court dockets by simplifying procedures. The search for truth is consciously given subsidiary priority. On the other hand, some 'consensual' procedures are aimed substantively at ascertaining the truth, such as those that follow the model of American 'cooperation' agreements, which offer significant mitigation or even dismissal to an accused who agrees to cooperate in solving other more serious crimes or testify as a prosecution witness in such serious cases. Here the perceived truth of the information offered by the bargaining defendant is crucial to the acceptance of the 'bargain'. This kind of bargaining that overseas American lawyers push as an effective vehicle to fight organized crime has been adopted, inter alia, in Moldova, Georgia and Russia. ${ }^{97}$ Some jurists have questioned whether use of such 'cooperation' agreements actually leads to the ascertainment of truth in the US. There have been too many innocent persons who have been cleared after being sentenced to long prison terms, or cven death, based in whole or in part on testimony resulting from suspect 'crown witnesses'. ${ }^{98}$

The new preference for the 'uncluttered' presentation of stipulated facts, which is indicative of plea bargaining and related manifestations of 'procedural economy', over the intuitive determination of raw facts by juries or the tutored decisions of professional judges, is perhaps the best reflection of the rise of 'economic' theories of jurisprudence. These 'displace empirical interest from the ragged history of issues to the calculable consequences of their resolution'. 99

\subsection{The Future of Lay Participation}

Although it was the Anglo-American jury court that gave rise to the modern model of adversarial, oral and public trial, only a few of the countries that have turned to adversarial procedures in recent reforms have introduced or returned to jury trial, even though the institution's abolition was the product of totalitarian, authoritarian and undemocratic regimes. The exceptions are the new jury systems introduced in Russia (1993), Spain (1995) and Georgia (2010).

94 Ibid. $348-55$.

95 Bordenkircher v. Hayes, 434 U.S. 357, 363 (1978); Brady v. United States, 397 U.S. 742,746 $(1970)$.

96 One can find exceptions in Estonia, Latvia, Lithuania, Moldova, Georgia, Nicaragua and Venezuela. Thaman (note 51) 346.

97 Ibid. 352-5.

98 Thaman, 'Consensual Penal Resolution' (note 92) 249.

99 Clifford Geertz, Local Knowledge. Further Essays in Interpretive Anthropology 218 (New York: Basic Books 1983). 
Despite the turn to adversary procedure, Latin America has made little use of lay judges in its criminal justice systems. Legislators have recently introduced mixed courts, in which lay and professional judges deliberate in a united panel, in Venezuela, Bolivia and the Argentine province of Córdoba. Otherwise, juries are primarily for the trial of homicide cases in Brazil, El Salvador, Nicaragua and Panama. The former Soviet republic of Kazakhstan introduced a mixcd court in 2007;100 Japan and South Korea did so in 2009. The Soviet mixed court, which replaced the Russian jury court in 1917, was adopted in nearly all countries in the socialist bloc following World War II. Most of these countries, whether or not they have become democracies, continue to use a court composed of one professional judge and two lay assessors in criminal cases (Poland, Czech Republic, Hungary, China and Vietnam, among others)..$^{101}$

The new jury systems in Russia and Spain both follow the European model based on question lists and majority verdicts, as do Belgium, Austria and Norway. Georgia, on the other hand, has introduced an American-style jury with general unanimous verdicts and non-appealable acquittals. ${ }^{102}$ In 2010 , the ECtHR decided that it could violate the right to a fair trial for a jury, in a particular case, to convict without giving reasons for its verdict. ${ }^{103}$ Thus a conflict has arisen between the tradition of the classic jury that may decide according to its conscience or intime conviction and the requirement that judgments bc reasoned to prevent arbitrariness and to ensure an effective right to appeal. Can a jury of twelve (as in Belgium, Russia or England and Wales) or nine (as in Spain) plausibly articulate the reasons why they determined certain facts to have been proved? The Spanish jury law, which went into effect in 1996, is revolutionary in that it requires the jurors to state the evidence upon which it relied and to give a 'succinct explanation of the reasons why they have declared, or refused to declare, certain facts as having been proved'. 104

\subsection{The Second Counter-Revolution: Victim's Rights over Defendant's Rights?}

In the United States, the prosecutor still has complete discretion as to whether or not to charge a case and on what terms to propose a plea bargain for settling it. This is not truc on the European continent, howcver, where victims can sometimes go to court to compel the prosecutor to charge a particular case where the prosecutor has refused to do so.

Victims can also sometimes file criminal charges, pursue attached civil actions for damages, and get a court-appointed attorney to represent them in court as a private prosecutor. In Spain, any member of the public may charge any crime as a popular

100 Thaman (note 73) 113.

101 Thaman (note 74) 1101.

102 The ECtHR lists the European countries that still have a 'traditional' jury system as Austria, Belgium, Georgia, Ireland, Malta, Norway (only on appeal), Russia, Spain and the United Kingdom (England, Wales, Scotland and Northern Ireland). The Swiss Canton of Geneva terminated its jury system in 2011. Taxquet v. Belgium (GC), no. 926/05 ECHR $\S 47$ (16 Nov. 2010).

103 Taxquet v. Belgium (note 103).

104 Thaman, 'Spain Returns' (note 61) 364. On the jurisprudence in Spain relating to reasoned jury verdicts, see Stephen C. Thaman, 'Should Criminal Juries Give Reasons for their Verdicts? The Spanish Experience and the Implications of the European Court of Human Rights Decision in Taxquet v. Belgium', 86 Chicago-Kent Law Journal 613-68 (2011). 
prosecutor' as well. ${ }^{105}$ This can lead to two and sometimes three prosecutors lined up against the accused and has generated criticism for re-introducing the notion of private revenge into the criminal trial. ${ }^{106}$

When the victim is accorded full procedural rights parallel to those of the defendant, the public prosecutor can use the victim as its 'Trojan horse' to protect against acquittals, as has been done in Russia. There, courts and prosecutors routinely violate the constitutional procedural rights of victims to build in reversible error in case the jury acquits. ${ }^{107}$

\section{FURTHER READING}

Bradley, Craig M. (ed) (2007). Criminal Procedure: A Worldwide Study. Durham, NC: Carolina Academic Press, 2nd edn.

Damaška, Mirjan R. (1986). The Faces of Justice and State Authority: A Comparative Approach to the Legal Process. New Haven, CT: Yale University Press.

Damaška, Mirjan R. (1997). Evidence Law Adrift. New Haven, CT: Yale University Press.

Langbein, John H. (1977). Torture and the Law of Proof: Europe and England in the Ancien Régime. Chicago: University of Chicago Press.

Langbein, John H. (2003). The Origins of Adversary Criminal Trial. Oxford: Oxford University Press.

Jackson, John, Máximo Langer and Peter Tillers (eds) (2008). Crime, Procedure and Evidence in Comparative and International Context: Essays in Honour of Professor Mirjan Damaška. Oxford: Hart Publishing.

Thaman, Stephen C. (2008). Comparative Criminal Procedure: A Casebook Approach. Durham, NC: Carolina Academic Press, 2nd edn.

Thaman, Stephen C. (ed.) (2010). World Plea Bargaining: Consensual Procedures and Avoidance of the Full Criminal Trial. Durham, NC: Carolina Academic Press.

Vidmar, Neil (ed.) (2000). World Jury Systems. Oxford: Oxford University Press.

Vogler, Richard (2005). A World View of Criminal Justice. Burlington, VT: Ashgate.

105 Many European countries allow private prosecution by victims for misdemeanor assaults or insults and similar cases, but not, as in Spain, in all cases. Thaman (note 60) 2530 .

106 In the first year of Spanish jury trials, private prosecutors invariably asked for maximum punishments and exorbitant civil damages, whereas the public prosecutor maintained a more moderate stance. Thaman, 'Spain Returns' (note 61) 397-401.

107 Thaman, 'Nullification' (note 61) 373-4. 